\title{
Application of Stochastic Optimal Control to Financial Market Debt Crises
}

\author{
JEROME L. STEIN \\ CESIFO WORKING PAPER NO. 2539 \\ CATEgORY 6: MONETARY POLICY AND INTERNATIONAL FinANCE \\ FEBRUARY 2009
}
An electronic version of the paper may be downloaded
- from the SSRN website: www.SSRN.com
- from the RePEc website:
- from the CESifo website:
www.RePEc.org
www.CESifo-group.org/wp




\title{
Application of Stochastic Optimal Control to Financial Market Debt Crises
}

\begin{abstract}
This interdisciplinary paper explains how mathematical techniques of stochastic optimal control can be applied to the recent subprime mortgage crisis. Why did the financial markets fail to anticipate the recent debt crisis, despite the large literature in mathematical finance concerning optimal portfolio allocation and stopping rules? The uncertainty concerns the capital gain, the return on capital and the interest rate. An optimal debt ratio is derived where the drift is probabilistic but subject to economic constraints. The crises occurred because the market neglected to consider pertinent economic constraints in the dynamic stochastic optimization. The first constraint is that the firm should not be viewed in isolation. The optimizer should be the entire industry. The second economic constraint concerns the modeling of the drift of the price of the asset. The vulnerability of the borrowing firm to shocks from the capital gain, the return to capital or the interest rate, does not depend upon the actual debt/net worth per se. Instead it increases in proportion to the difference between the Actual and Optimal debt ratio, called the excess debt. A general measure of excess debt is derived and I show that it is an early warning signal of the recent crisis.
\end{abstract}

JEL Code: C61, D81, D91, D92, G1, G11, G12, G14.

Keywords: stochastic optimal control, dynamic optimization, mortgage crisis, Ito equation, risk aversion, debt management, warning signals.

\author{
Jerome L. Stein \\ Department of Economics \\ Brown University \\ 182 George Street \\ USA - Providence, RI 02912 \\ Jerome_Stein@Brown.edu
}

\section{January 2009}

I thank Wendell H. Fleming and Raymond Rishel for their valuable suggestions. This paper was presented at the 2-nd Financial Risks International Forum, Risk management and Financial Crisis, Paris, France, March 19-20, 2009.

"How can it be that mathematics is, being after all a product of human thought independent of experience, is so admirably adapted to objects of realty?" (A. Einstein) 


\section{APPLICATION OF STOCHASTIC OPTIMAL CONTROL TO FINANCIAL MARKET DEBT CRISES}

\section{Jerome L. Stein}

When the subprime credit crisis of 2007 occurred, triple-A assets were downgraded to junk status within a few weeks or even a few days ${ }^{1}$. The rating agencies are at the center of the current crisis as many investors relied upon their ratings for the diverse financial and complex credit instruments. Why did the "Quants" and the credit markets fail to anticipate the recent debt crises, despite the large literature in mathematical finance concerning portfolio optimization? The rating process related the bond rating to the probability of default. One approach is to estimate a cumulative probability distribution of cash flows, based upon a mean and variance derived from historical experience. A value at risk $\mathrm{VaR}$ at the $1 \%$ level is derived. The probability is $1 \%$ that the loss would exceed this value. As the estimated cumulative probability distribution shifts to the left, the VaR probability of default rises. The rating would decline or the value of required collateral increases. Industry wide risk, where the returns on the portfolios of many firms are highly correlated, was ignored. Implicitly it was assumed that markets are extremely liquid. These assumptions were belied in the crisis of $2007-2008$. The methods of deriving a cumulative probability distribution and the VaR approach were questionable.

The mathematical finance literature takes a different approach. In that literature, the stock price is modeled with a probabilistic drift plus a geometric Brownian Motion term. As a rule the criterion function is the maximization of the expected logarithm of the stock price or a portfolio of stocks over some horizon. The aim of most authors is to derive optimal stopping or switching rules, given that the drift will change at some unknown time. In other cases, the aim was to determine the optimal portfolio allocation, based upon a probabilistic and unobserved drift plus a Brownian Motion term. A general problem is to find an alarm/early warning signal when to take some action. Alternative strategies are proposed to determine when the drift has changed.

Blanchet-Scalliet et al (B-S) derive an optimal portfolio allocation, given that the drift will change only once at some unknown time They contrast three approaches to determine what is an appropriate "alarm signal" when to take some action. In one, the optimization is based upon a misspecified model where future changes are ignored. The second is non-theoretical. A

\footnotetext{
${ }^{1}$ Crouhy et al is a basic reference for a description of the subprime mortgage crisis and the players involved.
} 
moving average is used to estimate when the drift has changed. Trading rules are just based upon the history of the asset price. The third are two model-detect strategies. The main mathematical tool used to obtain these two stopping rules is the process $\mathrm{F}_{\mathrm{t}}$, the conditional probability that the unknown change in the drift has already occurred. For each procedure, the trader decides to switch his stock portfolio when $F_{t}$ is bigger than a given quantity. They use simulations to evaluate which approach is optimal.

In Rishel's model (2006) the drift changes back and forth in a probabilistic way, and there is an added Brownian Motion term to the stock price. He determines the optimal selling time of the stock. Like B-S, he uses the conditional probability that the trend has changed, based upon nonlinear filtering results that involve the history of the price and the current innovation. These two papers are related to the work of Lister and Shiryayev, Karatzas and Shreve and the Kalman filter involving nonlinear filtering for hidden Markov chains. Zhang's model is similar to Rishel's. Zhang derives a set of target prices and stop loss limits. The stock is sold when the price reaches either one of these limits. Beckmann's model concerns a stock that pays a dividend and where the logarithm of the price follows a Brownian Motion with drift. The alternative to holding the stock is a safe asset with a fixed interest rate. He determines when it is optimal to sell the stock. His paper determines an optimal switching rule, particularly when there is no drift, and is a useful introduction to the switching analysis. The papers by Platen-Rebello and BieleckiPliska assume that the logarithm of the stock price has a trend plus a Brownian Motion term. The trend is ergodic mean reverting. The object is to determine the optimal portfolio of the risky stock and safe asset. Analyses of applications of stochastic optimal control (SOC) to mathematical finance are in Fleming (1999), Fleming and Soner 92006) and in Yin and Zhang (2004).

A focus upon the optimum debt ratio is more general than the switching/limit price/stop loss approch for the following reason. The ratio of debt/net worth is equal to the ratio of the risky asset/net worth minus one. Therefore variations in the debt ratio correspond 1-1 to variations in the ratio of risky assets/net worth. Switching between the stock and the safe asset mean variations in the debt ratio. Hence the determinants of the optimal debt ratio in continuous time when the drift is probabilistic correspond to the determinants of the switching in continuous time between the risky and the safe asset. 
This interdisciplinary paper is designed to explain how the mathematical techniques of stochastic optimal control can be applied to the economics underling the recent debt crises. The challenges are how to model the economic phenomena, how to evaluate what are the strengths and weaknesses of alternative mathematical approaches and then derive empirical early warning signals of crises. This interdisciplinary paper is aimed at both applied mathematicians who are looking for applications of the mathematics and to those who may be looking for analytical tools for purposes of policy or debt management.

There are several features of the approach in this paper. First: The investors are assumed to be the industry as a whole. The focus is upon systemic risk. This builds in the correlations among the returns. The mathematical finance literature concerning credit risk used by the "Quants" is mainly concerned with transferring risk to other institutions quickly and at negligible cost. When the risk is systemic, the entire group is in trouble. Firms own huge shares of other firms. When the market sank, there was a domino effect. The insurance companies were also vulnerable, and no one can save the other. Second, the optimizer is assumed to be very risk averse. An infinite penalty is placed upon bankruptcy. Third, the failure of Long term Capital Management $^{2}$ (LTCM) should have taught Wall Street and investors that even models designed by geniuses are subject to error and uncertainties. One can never be sure what is the correct way to model the stochastic processes. I first present a general stochastic optimization model and then analyze special cases. I derive a relation between errors of measurement of the optimal debt, resulting from model uncertainty, and the loss of expected growth.

My focus and example are based upon the sub-prime mortgage crisis ${ }^{3}$ of 2007. The crisis occurred because the market neglected to consider the above features. The vulnerability of the borrowing firm and the entire industry to shocks from either the return to capital, the interest rate or capital gain does not depend upon the current ratio of debt/net worth. Instead the vulnerability depends upon the difference between the Current and Optimal debt ratios, called the excess debt. The optimal debt ratio may be time varying. A general measure of excess debt is derived and I show that it is an early warning signal of the recent mortgage crisis.

\footnotetext{
2 The book by Lowenstein describes the LTCM history in a clear and dramatic way .

${ }^{3}$ The agricultural debt crisis of the 1980s followed a similar pattern. See Stein (2004).
} 


\section{Sketch of The Crisis}

Bubbles are based upon anticipated but non-sustainable capital gains that are not closely related to the net productivity of capital. As a consequence, the rising debt payments/net income makes the system more vulnerable to shocks either from the capital gains, productivity of capital or the interest rate. A crisis then occurs with bankruptcies and defaults.

Crouhy et al and Gerardi et al provide detailed descriptions of the sub-prime mortgage crisis of 2006-2007. Demyanyk and Van Hemert utilized a data-base containing information about one half of all subprime mortgages originated between 2001 and 2006. They explored to what extent the probability of delinquency/default can be attributed to different loan and borrower characteristics and appreciation of housing price. The relevant variables are graphed in normalized form in figure 1.

From 1998-2005 rising home prices produced capital gains (CAPGAIN) more than two standard deviations above average, which increased owner equity. This induced a supply of mortgages, and the totality of household financial obligations as a percent of disposable personal income (DEBTRATIO) rose by two standard deviations. In about $45-55 \%$ of the cases, the purpose of the sub-prime mortgage taken out in 2006 was to extract cash by refinancing an existing mortgage loan into a larger mortgage loan. The quality of loans declined. The share of loans with full documentation substantially decreased from $69 \%$ in 2001 to $45 \%$ in 2006 (Demyanyk and Van Hemert). The low interest rates and rises in housing prices and owner equity induced a demand for mortgages by banks, financial intermediaries and hedge funds, which were searching for higher returns. Financial intermediaries and funds held packages of mortgage-backed securities either directly as asset-backed securities or indirectly through investment in central funds. The purchases were financed by short-term bank loans. The financial intermediaries, the hedge funds and the banks thought that expected return was rising relative to risk, because equity was rising due to the rise in home prices.

The large capital gains from 2003 - 2005 fell drastically from $12.2 \%$ pa in $2006 q 1$ to $1.79 \%$ pa in $2007 q 3$. The delinquency rates in 2006 , for each age of mortgage, were the highest in the previous five years. Figure 1 shows that the capital gain was the lowest over the period.

Many borrowers had little equity in their homes and found it difficult to sell or to refinance, because the debt exceeded the market value of the home. It was cheaper to default and avoid debt service than to rent new housing. Financial intermediaries and investors who 
purchased packages of sub-prime loans or bought securities backed by them reported billions of dollars of losses. The massive unwinding of positions by highly leveraged investors such as hedge funds pushed the prices of both low and high quality sub-prime securities lower. All of the firms have to mark-to-market to the fire-sale prices. This created a domino effect. Equity was further reduced, and the debt/equity ratio of borrowers and financial intermediaries rose. Banks and financial intermediaries reacted by reducing the supply of credit to the economy, and induced the Federal Reserve to change its monetary policy, the Treasury to advocate a bail-out of the banking industry and the Congress to support the housing industry.

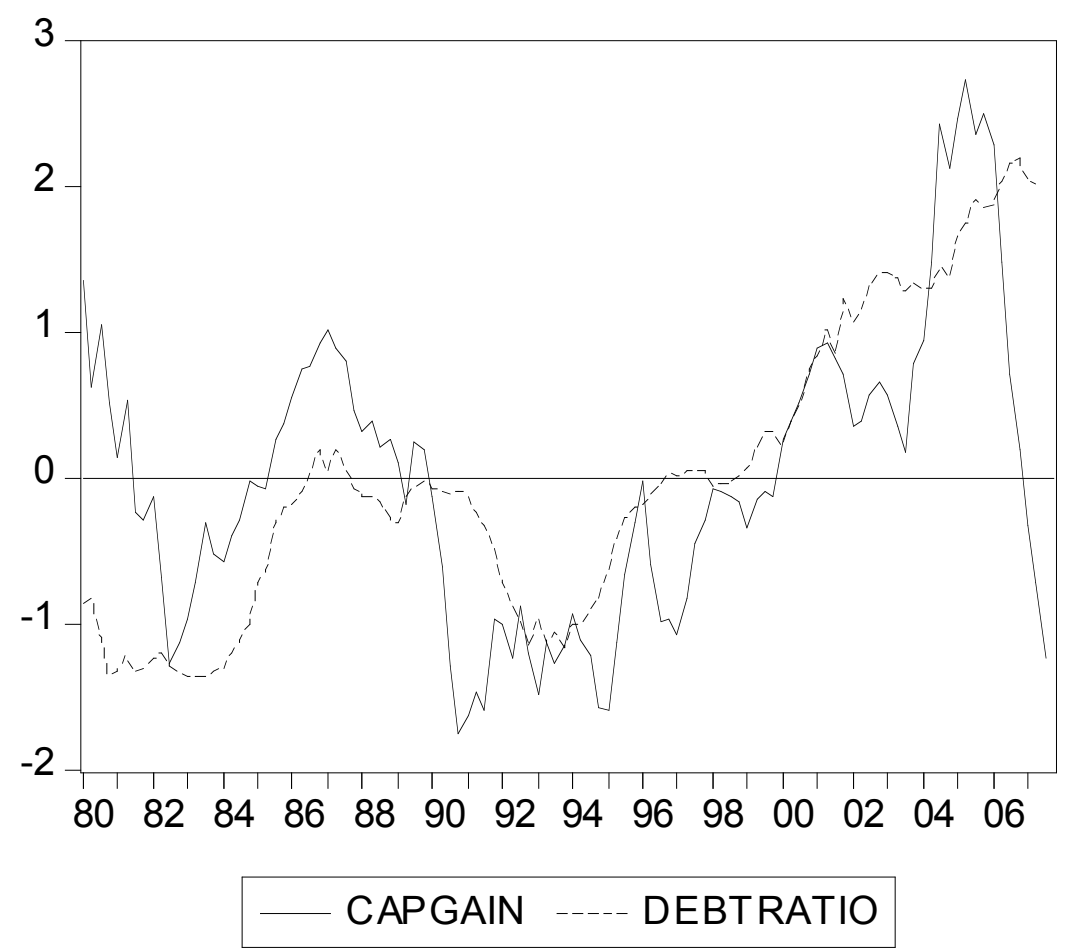

Figure 1. Mortgage Market Bubble. Normalized variables $=($ variable - mean $) /$ standard deviation. CAPGAIN $=4 q$ appreciation of single-family US Housing prices HPI, Office Federal Housing Enterprise Oversight (OFHEO); Household debt ratio DEBTRATIO = household financial obligations as a percent of disposable income. Source: Federal Reserve Bank of St. Louis, FRED, Series FODSP.

According to the survey reported by Gerardi et al, there was agreement among the rating agencies that if housing prices fell drastically, say $10-15 \%$, there would be a dramatic increase in problems in the subprime market. Table 1/histogram below shows that the annual change of housing prices since 1992 was never negative. Since the probability of such an event was 
deemed extremely low, the expected price change was positive. The onset of the crisis can be dated in the second quarter of 2007 when the cost of insuring subprime backed securities rose drastically. On May 17, 2007 Ben Bernanke stated: "We do not expect significant spillovers from the subprime market to the rest of the economy or the financial system."

Alan Greenspan's testimony before Congress in October 2008 is very important. He admitted that he had put too much faith in the self-correcting power of the free markets and had failed to anticipate the self-destructive power of wanton mortgage lending. He stated that: "This modern risk-management paradigm held sway for decades. The whole intellectual edifice, however, collapsed in the summer of last year".

The market, the Federal Reserve, investors and rating agencies lacked a theoretically consistent model/method of analysis that would provide adequate Early Warning Signals (EWS) of a forthcoming crisis. I apply several techniques in the mathematical literature of stochastic optimal control (SOC) to derive an optimal debt in an environment where there are risks on both the asset and liabilities sides.

\subsection{Outline of the paper}

The mortgage debt crisis involved borrowers, financial intermediaries, banks, brokerage houses, hedge funds, insurance companies and ultimate investors. The shocks that affected one firm simultaneously affected the others. The failure of one component led to the failure of another one downstream. It was like an epidemic. For this reason my analysis focuses upon the entire industry, which is the aggregate of financial intermediaries. What is an excess debt for the aggregate of the financial intermediaries? How should the optimizer/decision maker evaluate the debt and net worth of the financial intermediary over a period, a horizon of length $\mathrm{T}$ from the present $\mathrm{t}=0$ ? An optimization must balance risk against expected return.

The optimal debt/net worth, or optimal capital requirement, will depend upon the underlying stochastic processes. The crises have occurred because the market made untenable assumptions about the underlying stochastic processes. In part 2, I present a general stochastic model and solve for the optimal ratio of debt/net worth ${ }^{4}$. Particular models differ concerning the specification of the probabilistic drift. One can never be sure of what is the correct model for

\footnotetext{
${ }^{4}$ The method of analysis used in this paper has its origins in Fleming and Stein (2004). Applications to international finance and debt of this method are in Stein (2005), (2006).
} 
optimization. There will always be an error of measurement of what is the "true" optimal debt ratio. We therefore derive a relation between errors of measurement of the optimal debt resulting from model uncertainty and the loss of expected growth of net worth. Part 2 contains the basic mathematical structure.

Three models are presented. Optimization Model I, a special case of the general model, imposes a long run economic constraint on the drift to preclude a "free lunch". A "free lunch" occurs when the trend of the capital gains exceeds the rate of interest. One continually borrows and spends, refinances the loan and pays the interest from the capital gain. A situation where there is a "free lunch", or "money machine" where the capital gains exceeds the rate of interest, is not sustainable. Model I is solved in part 3 for the optimal ratio of debt/net worth and for the maximum expected growth of net worth.

Optimization Model II, which is the subject of part 4, imposes shorter run constraints on the probabilistic drift. Model III presented in Part 5 explains how a Bayesian approach which fails to impose either of these constraints led to the bubble and subsequent crisis. There is reason to believe that this model describes the market behavior.

The conclusions are as follows. (a) The ratio debt/net worth per se is not a significant explanation of defaults. (b) As the debt ratio exceeds the derived optimum, the expected growth of net worth declines, risk rises relative to expected return and default becomes ever more likely. Part 6 applies the mathematical analysis in the earlier parts to the mortgage debt crisis. We derive early warning signals EWS of a debt crisis, consistent with constrained optimization models I and II, and show how the excess debt led to the mortgage debt crisis. This paper shows how the techniques of stochastic optimal control can be fruitfully applied to an important and timely economic problem.

\section{A General Intertemporal Optimization Model}

\subsection{Basic equations}

The financial intermediary has a net worth $\mathrm{X}(\mathrm{t})$ equal to the value of assets or capital $\mathrm{K}(\mathrm{t})$ less debt $\mathrm{L}(\mathrm{t})$, equation (1). Capital $\mathrm{K}(\mathrm{t})=\mathrm{P}(\mathrm{t}) \mathrm{Q}(\mathrm{t})$ is the product of a deterministic physical quantity $\mathrm{Q}(\mathrm{t})$ times the stochastic price $\mathrm{P}(\mathrm{t})$ of the capital asset.

(1) $\mathrm{X}(\mathrm{t})=\mathrm{K}(\mathrm{t})-\mathrm{L}(\mathrm{t})=\mathrm{P}(\mathrm{t}) \mathrm{Q}(\mathrm{t})-\mathrm{L}(\mathrm{t})$. 
Equation (2) or (2a) is a flexible criterion function. The optimizer wants the financial intermediary to be profitable and generate a high return to the stockholders, but is very risk averse. He places a heavy penalty on a debt that would lead to a zero net worth, bankruptcy where net worth $X=0$. Equation (2a) satisfies these criteria since the object is to maximize the expected growth of net worth and where bankruptcy $\mathrm{X}(\mathrm{T})=0$ implies that $\mathrm{W}=\mathrm{E} \ln [\mathrm{X}(\mathrm{T}) / \mathrm{X}(0)]$ is minus infinity. The asterisk denotes the maximum value.

(2) $\mathrm{W}^{*}(\mathrm{X}, \mathrm{T})=\max _{\mathrm{f}} \mathrm{E} \ln [\mathrm{X}(\mathrm{T}) / \mathrm{X}(0)], \quad \mathrm{f}=\mathrm{L} / \mathrm{X}=\mathrm{debt} /$ net worth (2a) $E[X(T)]=X(0) e^{W(X, T)}$

The control variable is the debt ratio $\mathrm{f}(\mathrm{t})=\mathrm{L}(\mathrm{t}) / \mathrm{X}(\mathrm{t})$. The optimizer attempts to determine the optimal debt ratio, or the optimum leverage to satisfy eqn.(2). The next steps are to explain the stochastic differential equation for net worth, relate it to the debt ratio, and specify what are the sources and characteristics of the risk and uncertainty.

In view of equations (1), (2), focus upon the change in net worth $\mathrm{dX}(\mathrm{t})$ of the financial intermediaries. It is the equal to the change in capital $\mathrm{dK}(\mathrm{t})$ less the change in debt $\mathrm{dL}(\mathrm{t})$. The change in capital $d K(t)=d(P(t) Q(t))$ equation (3) has two components. The first is the change due to the change in price of capital asset, which is the capital gain or loss, $\mathrm{K}(\mathrm{t})(\mathrm{dP}(\mathrm{t}) / \mathrm{P}(\mathrm{t}))$ term. The second is investment $\mathrm{I}(\mathrm{t})=\mathrm{P}(\mathrm{t}) \mathrm{dQ}(\mathrm{t})$ the change in the quantity times the price.

(3) $d K(t)=d(P(t) Q(t))=Q(t) d P(t)+P(t) d Q(t)=K(t) d P(t) / P(t)+I(t)$

The change in debt $\mathrm{dL}(\mathrm{t})$, equation (4), is the sum of expenditures less income. Expenditures are the debt service $i(t) L(t)$ at interest rate $i(t)$, plus investment $I(t)=P(t) d Q(t)$ plus the sum of consumption, dividends and distributed profits $C(t)$. Income $Y(t)=\beta(t) K(t)$ is the product of capital $\mathrm{K}(\mathrm{t})$ times $\beta(\mathrm{t})$ its productivity.

(4) $d L(t)=i(t) L(t)+P(t) d Q(t)+C(t)-\beta(t) K(t)$.

Combining these effects, the change in net worth $d X(t)=d K(t)-d L(t)$ is equation (5).

(5) $d X(t)=d K(t)-d L(t)=K(t)[d P(t) / P(t)+\beta(t) d t]-i(t) L(t) d t-C(t) d t$.

Since net worth is capital less debt, equation (6) describes the dynamics of net worth equation (5) in terms of the ratio $\mathrm{f}(\mathrm{t})=\mathrm{L}(\mathrm{t}) / \mathrm{X}(\mathrm{t})$ of debt net worth and consumption ratio $\mathrm{c}(\mathrm{t})=\mathrm{C}(\mathrm{t}) / \mathrm{X}(\mathrm{t}) \geq 0$. Since capital/net worth $\mathrm{k}(\mathrm{t})=\mathrm{K}(\mathrm{t}) / \mathrm{X}(\mathrm{t})=(1+\mathrm{f}(\mathrm{t}))$, the control variable could be either the debt ratio or the capital ratio.

(6) $d X(t)=X(t)\{(1+f(t))[d P(t) / P(t)+\beta(t) d t]-i(t) f(t) d t-c(t) d t\}$. 
A simplifying assumption is that the outflow consumption, distributed profits and dividends are paid from the current productivity of capital, equation (7). If the latter is negative, then $\mathrm{c}(\mathrm{t})=0$.

(7) $\mathrm{c}(\mathrm{t})=\beta(\mathrm{t}) \geq 0$.

In that case, the stochastic differential equation (6) becomes (8).

$(8) d X(t)=X(t)[(1+f(t))(1 / P(t)) d P(t)+(\beta(t)-i(t)) f(t) d t]$

The optimization of (2) subject to (8) depends upon the stochastic processes underlying the $\mathrm{dP}(\mathrm{t}) / \mathrm{P}(\mathrm{t}), \beta(\mathrm{t})$ and $\mathrm{i}(\mathrm{t})$ variables. The productivity of capital $\beta(\mathrm{t})$ and interest rate $\mathrm{i}(\mathrm{t})$ are always observable but change over time. However the change in price $\mathrm{dP}(\mathrm{t})$ from $\mathrm{t}$ to $\mathrm{t}+\mathrm{dt}$ is unpredictable, given all the information through present time $t$.

A very important consideration is the model for the prices $\mathrm{P}(\mathrm{t})$. In order to take into account the ups and downs of the market, the model should allow periods in which prices have increasing trends and periods in which prices have decreasing trends. We shall consider models for prices that have these increasing and decreasing trends. For each of these models the differential of the prices has the form

(9) $d P(t)=P(t)(a(t) d t+\sigma d w(t))$

Where $\mathrm{w}(\mathrm{t})$ is a Brownian motion and the drift process $\mathrm{a}(\mathrm{t})$ is a slowly varying random process which can have both positive and negative values. The positive periods of $a(t)$ are periods of relative growth of prices, the negative periods of $\mathrm{a}(\mathrm{t})$ are periods of relative decline of prices. The Brownian motion $\mathrm{w}(\mathrm{t})$ gives the rapid short term variation of the prices.

In the general model we derive the optimal debt ratio, without specifying what is the explicit value a(t) of the time varying drift. In part 3/Model I, the price equation (9) is specified to be an ergodic mean reverting process and thereby an explicit value for the drift $a(t)$ is obtained. Then using this value, the optimal debt ratio is derived for Model I. This is our preferred model. Part 4 concerns Model II. On the other hand, as explained in part 5 below, market Model III based upon a Bayesian analysis assumed an unsustainable value for a(t), the drift, which led to the bubble and subsequent collapse. 


\subsection{Optimization in the general Model}

Consider the problem of choosing the debt ratio $f(t)$ as a function of the past values of the price $P(t)$, the interest rate $i(t)$, and the productivity of capital $\beta(t)$ to maximize the expected value of the logarithm of net worth at a fixed final time T, criterion (2) above $\max _{\mathrm{f}(\mathrm{t})} \mathrm{E}[\ln \mathrm{X}(\mathrm{T})], \quad \mathrm{X}(0)=1$.

This choice is to be made subject to $\mathrm{X}(\mathrm{t})$ being a solution of equation (10) $d X(t)=X(t)[(1+f(t)) a(t)+(\beta(t)-i(t)) f(t)] d t+X(t)(1+f(t)) \sigma d w(t)]$.

When $a(t)$ can be determined from past values of the prices $P(t)$, the choice of $f(t)$ can depend on the information set $\mathfrak{s}(\mathrm{t})=\{\mathrm{P}(\mathrm{t}), \mathrm{i}(\mathrm{t}), \beta(\mathrm{t}), \mathrm{a}(\mathrm{t})\}$.

To carry out this optimization notice that (10) and Ito's differential rule imply

$(11) d \ln X(t)=[(1+f(t)) a(t)+(\beta(t)-i(t)) f(t)] d t+(1+f(t)) \sigma d w(t)-(1 / 2)(1+f(t))^{2} \sigma^{2} d t$.

Or in integrated form

(12) $\ln \mathrm{X}(\mathrm{T})=\ln \mathrm{X}(0)+\int_{\mathrm{o}}^{\mathrm{T}}\left[(1+\mathrm{f}(\tau)) \mathrm{a}(\tau)+(\beta(\tau)-\mathrm{i}(\tau)) \mathrm{f}(\tau)-(1 / 2)(1+\mathrm{f}(\tau))^{2} \sigma^{2}\right] \mathrm{dt}$

$+\int_{0}^{\mathrm{T}}(1+\mathrm{f}(\tau)) \sigma \mathrm{dw}(\tau)$.

Thus taking expected values,

(13) $\mathrm{E}[\ln \mathrm{X}(\mathrm{T})]=\ln \mathrm{X}(0)+\mathrm{E}\left[\int_{0}^{\mathrm{T}}\left\{(1+\mathrm{f}(\mathrm{t})) \mathrm{a}(\mathrm{t})+(\beta(\mathrm{t})-\mathrm{i}(\mathrm{t})) \mathrm{f}(\mathrm{t})-(1 / 2)(1+\mathrm{f}(\mathrm{t}))^{2} \sigma^{2}\right\} \mathrm{dt}\right.$

The integrand in (13) is maximized when

(14) $\mathrm{a}(\mathrm{t})+\beta(\mathrm{t})-\mathrm{i}(\mathrm{t})-(1+\mathrm{f}(\mathrm{t})) \sigma^{2}=0$.

Thus $\mathrm{f}^{*}(\mathrm{t})$ in equation (15) is the optimum (denoted by an asterisk) debt ratio in the general case. (15) $\mathrm{f}^{*}(\mathrm{t})=\left[\mathrm{a}(\mathrm{t})+\beta(\mathrm{t})-\mathrm{i}(\mathrm{t})-\sigma^{2}\right] / \sigma^{2}$

It depends upon information set $\Im(t)$, the current observations of productivity of capital $\beta(\mathrm{t})$ interest rate $\mathrm{i}(\mathrm{t})$, and the past history of prices. The specification of the price equation (9) for the alternative models determines what is the appropriate value of a(t) the drift. The value of the drift a(t) thereby obtained is substituted in eqn. (15) to obtain the optimal debt ratio for the alternative models.

\subsection{Model Uncertainty, Excess Debt and Vulnerability to Shocks: General Case} Optimal risk management should focus upon the debt ratio $f(t)=L(t) / X(t)$ that maximizes the expected growth of the logarithm of net worth. This is a risk averse strategy for reasons explained in eqn. (2a). Risk management should avoid having debt ratios where the expected growth of the logarithm of net worth is very low or negative. Define the excess debt $\Psi(\mathrm{t})=(\mathrm{f}(\mathrm{t})$ $\left.-\mathrm{f}^{*}(\mathrm{t})\right)$ as the difference between the observed actual debt ratio $\mathrm{f}(\mathrm{t})$ and the optimal debt ratio 
$\mathrm{f}^{*}(\mathrm{t})$. In this part, we derive an equation for the excess debt in the general case and show that the greater the excess debt the lower is the expected growth rate of net worth.

One can never be sure of what is the correct model for optimization. There will always be an error of measurement of what is the "true" optimal debt ratio. We therefore derive a relation between errors of measurement of the excess debt resulting from model uncertainty and the loss of expected growth of net worth. We then illustrate them using figure 2 .

The growth of net worth over a short period, equation (11) for the general case, is written as eqn. (16). The corresponding expected growth is eqn. (16a). The variance of $d[\ln X(t)]$ is eq. (16b).

(16) $d[\ln X(t)]=W(f(t))+(1+f(t)) \sigma d w \quad$ Growth over a short period

(16a) $\mathrm{W}(\mathrm{f}(\mathrm{t}))=\mathrm{E}\left[\mathrm{d} \ln (\mathrm{X}(\mathrm{t})]=(1+\mathrm{f}(\mathrm{t})) \mathrm{a}(\mathrm{t})+\left(\beta(\mathrm{t})-\mathrm{i}(\mathrm{t}) \mathrm{f}(\mathrm{t})-(1 / 2)(1+\mathrm{f}(\mathrm{t}))^{2} \sigma^{2}\right.\right.$ Expected Growth (16b) $\operatorname{var} d[\ln X(t)]=(1+f(t))^{2} \sigma^{2} d t$

The relation between excess debt $\Psi(\mathrm{t})=\left(\mathrm{f}(\mathrm{t})-\mathrm{f}^{*}(\mathrm{t})\right)$ and the difference $\left[\mathrm{W}^{*}(\mathrm{t})-\mathrm{W}(\mathrm{t})\right]$ between maximal and actual expected growth is derived as follows. The expected growth of net worth $\mathrm{W}(\mathrm{f}(\mathrm{t}))$ is a quadratic function of the debt ratio $\mathrm{f}(\mathrm{t})$, which is graphed in figure 2. Since $\mathrm{W}(\mathrm{f}(\mathrm{t}))$ is quadratic in $\mathrm{f}(\mathrm{t})$, it has a three term Taylor expansion, eqn. (17), about $\mathrm{f}^{*}(\mathrm{t})$, the optimum value.

(17) $\mathrm{W}(\mathrm{f}(\mathrm{t}))=\mathrm{W}\left(\mathrm{f}^{*}(\mathrm{t})\right)+\mathrm{W}^{\prime}\left(\mathrm{f}^{*}(\mathrm{t})\right)\left(\mathrm{f}(\mathrm{t})-\mathrm{f}^{*}(\mathrm{t})\right)+(1 / 2) \mathrm{W}^{\prime \prime}\left(\mathrm{f}^{*}(\mathrm{t})\right)\left(\mathrm{f}(\mathrm{t})-\mathrm{f}^{*}(\mathrm{t})\right)^{2}$

It attains a maximum $\mathrm{W}^{*}(\mathrm{t})=\mathrm{W}\left(\mathrm{f}^{*}(\mathrm{t})\right)$ when the debt ratio is optimal at $\mathrm{f}^{*}(\mathrm{t})$, as defined in eqn. (15) for the general model. Hence $W^{\prime}\left(f^{*}(t)\right)=0$ and $W^{\prime \prime}(f)=-\sigma^{2}$.

It follows that the difference between the maximum expected growth $\mathrm{W}\left(\mathrm{f}^{*}\right)$ and the actual growth W(f) is equation (18). It is proportional to $\Psi(\mathrm{t})^{2}$ the square of the excess debt. (18)

$$
\left[\mathrm{W}^{*}(\mathrm{t})-\mathrm{W}(\mathrm{t})\right]=(1 / 2) \sigma^{2}\left(\mathrm{f}(\mathrm{t})-\mathrm{f}^{*}(\mathrm{t})\right)^{2}=(1 / 2) \sigma^{2} \Psi(\mathrm{t})^{2}
$$

The terms $\mathrm{W}^{*}(\mathrm{t})$ with the asterisk refer to the case where the debt ratio is always optimal $\mathrm{f}^{*}(\mathrm{t})$ but time varying, and the terms $\mathrm{W}(\mathrm{t})$ refer to the actual debt ratios $\mathrm{f}(\mathrm{t})$ during the period. In figure 2 , if one thought that $\mathrm{f} 1$ was the optimum debt ratio at time $\mathrm{t}$ when it is really $\mathrm{f}^{*}$, the loss of expected growth of net worth during the period of length dt is ( $\left.\mathrm{W}^{*}-\mathrm{W} 1\right)$.

There are several important implications of eqn. (18). First, as $f(t)$ rises above $f^{*}(t)$, the economy's growth of net worth is ever more vulnerable to shocks, from the capital gains, productivity of capital and the interest rate. This occurs because actual growth eq. (16) is the sum of expected growth $\mathrm{W}(\mathrm{f}(\mathrm{t}))$ plus the random term. When there is an excess debt, expected growth 
declines. Bankruptcy and a crisis become ever more probable. Second, one can never know what is the "true" model and hence what is the "true" optimal debt ratio $\mathrm{f}^{*}(\mathrm{t})$. One chooses what seems to be the optimal debt ratio based upon what seems to be the correct model. There will always be a specification error at any time $t$ measured as the excess debt $\Psi(t)=\left(f(t)-f^{*}(t)\right)$. Eqn. (19), which is the integral of eq. (18), states precisely what is the loss of expected growth of net worth as a result of using a non-optimal control, debt ratio $\mathrm{f}(\mathrm{t})$.

(19) $\mathrm{E}\left[\ln \mathrm{X}^{*}(\mathrm{~T})-\ln \mathrm{X}(\mathrm{T})\right]=\int^{\mathrm{T}}[\mathrm{W} *(\mathrm{t})-\mathrm{W}(\mathrm{t})] \mathrm{dt}=(1 / 2) \int^{\mathrm{T}} \sigma^{2} \Psi(\mathrm{t})^{2} \mathrm{dt}$.

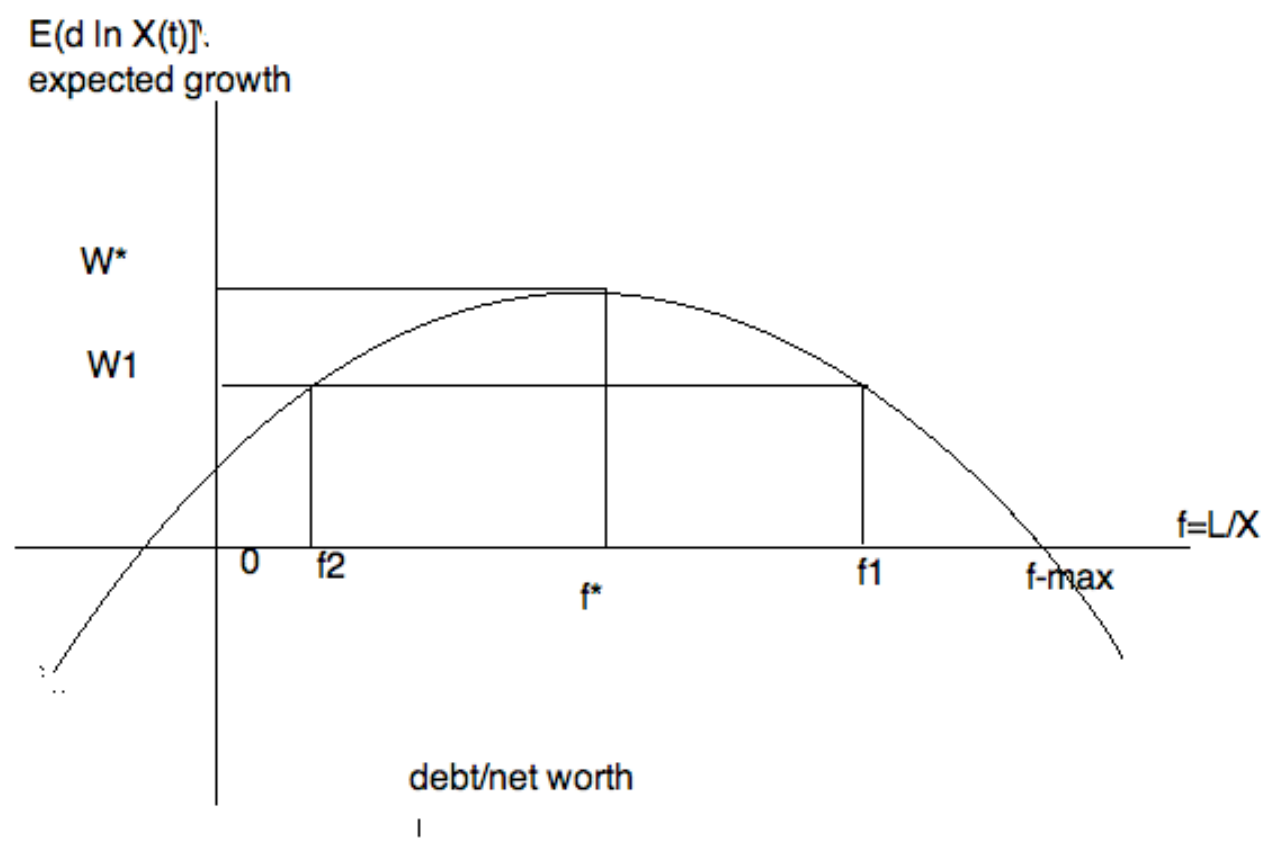

Figure 2. Expected growth in net worth $\mathrm{W}(\mathrm{f}(\mathrm{t}))=\mathrm{E}[\mathrm{d} \ln \mathrm{X}(\mathrm{t})]$ is a concave function of the debt ratio $\mathrm{f}(\mathrm{t})=\mathrm{L}(\mathrm{t}) / \mathrm{X}(\mathrm{t})$. The optimum ratio is $\mathrm{f}^{*}(\mathrm{t})$, and maximum expected growth rate is $\mathrm{W}^{*}$. Debt ratio in period $t=1$ is $f 1$ and in period $t=2$ it is $f 2$. The average is $f^{*}$. Excess debt $\Psi^{2}(t)=$ $\left(\mathrm{f} 1-\mathrm{f}^{*}\right)^{2}=\left(\mathrm{f} 2-\mathrm{f}^{*}\right)^{2}$ corresponds to the sacrifice of expected growth $\left(\mathrm{W}^{*}-\mathrm{W} 1\right)=(1 / 2)\left(\sigma^{2} \Psi(\mathrm{t})^{2}\right.$ in each period.

Third, errors of using non-optimal debt ratios do not average out. Suppose that the optimal debt ratio is $\mathrm{f}^{*}$ in figure 2 for two periods. In period $t=1$ the actual ratio is $f 1$, in period $t$ $=2$ it is $\mathrm{f} 2$, and the average is $(1 / 2)(\mathrm{f} 1+\mathrm{f} 2)=\mathrm{f}^{*}$. The square of the errors are $\Psi(\mathrm{t})^{2}$ imply a loss of $\left(\mathrm{W}^{*}-\mathrm{W} 1\right)$ in each period so that the errors of using an incorrect debt ratio do not average out to zero. 


\section{Model I: Ergodic Mean Reversion Drift.}

Model I is a special case of the general model above. It is based upon the "no free lunch" constraint. This constraint is satisfied by assuming that the price equation is an ergodic mean reversion (Ornstein-Ulenbeck) process. A specific equation is thereby obtained for the drift $\mathrm{a}(\mathrm{t})$, which is substituted into eqn. (15) and an optimal debt ratio is determined. This is our preferred model from which we derive Early Warning Signals of a debt crisis. First, we explain the how the violation of the "no free lunch" constraint below led to the housing bubble and its collapse. Second, the specific price equation, corresponding to (9), is developed. Third, the optimal debt ratio, corresponding to (15), is derived for Model I.

\subsection{The No Free Lunch Constraint}

A crucial requirement in selecting an optimizing model is that the drift $a(t)$ in the capital gains equation (9) should be constrained to avoid bubbles or non-sustainable debt ratios. Models I and II build in the constraint. The "market" used model III that led to improper estimates of the drift $\mathrm{a}(\mathrm{t})$, and hence to incorrect and unsustainable debt ratios. This serious error led to the bubble and the crisis. A bubble is a situation described by equation (20) where: (i) net worth grows due to the capital gains, (ii) the capital gain $\pi(\mathrm{t})$ exceeds $\mathrm{i}(\mathrm{t})$ the interest on the debt, (iii) which in turn exceeds the productivity of capital. The only way that the borrower can pay the interest is by cashing in on the capital-gain.

(20) $\pi(\mathrm{t})>\mathrm{i}(\mathrm{t})>\beta(\mathrm{t}) . \quad$ BUBBLE $\quad \pi(\mathrm{t})=$ capital gain $=[\ln \mathrm{P}(\mathrm{t}+\delta \mathrm{t})-\ln \mathrm{P}(\mathrm{t})] / \delta \mathrm{t}$

The no free lunch constraint is that the price of an asset cannot continue to grow at a rate greater than the rate of interest for any significant period. Say that the borrower incurs a debt L(t) to purchase capital $K(t)$, such as "housing", $L(t)=K(t)>0$. Cash flow is $K(t) \pi(t)$ and interest payments are $\mathrm{i}(\mathrm{t}) \mathrm{L}(\mathrm{t})$. As occurred in the debt crisis described in part 1, as long as the net cash flow $[(\pi(t)-i(t)]$ was positive, more debt was refinanced to either spend or purchase a newer home. One has a money machine. Continue to borrow and spend, and pay the interest from the capital gain. A situation where there is a "free lunch", or "money machine" where $[(\pi(t)-\mathrm{i}(\mathrm{t})]>$ 0 , is not sustainable.

Alternatively, let $P V(t)$ in eq. (21) be the present value of the asset. The trend price is $\mathrm{P}^{*}(\mathrm{t})=\mathrm{P}^{*}(0) \exp (\rho \mathrm{t})$, where $\rho$ is the trend and $\mathrm{i}$ is the nominal rate of interest. 
(21) $\operatorname{PV}(\mathrm{t})=\mathrm{P} *(0) \mathrm{e}^{(\rho-\mathrm{i}) \mathrm{t}}$.

If the trend rate $\rho$ exceeds the nominal rate of interest, the present value becomes infinitely large over time. This condition, which violates the "no free lunch" constraint, is not sustainable.

Figure 1 and table 1/histogram describe the statistics underlying the capital gains CAPGAINS variable $\pi(t)$, the four- quarter appreciation of US housing prices. Figure 1 shows that there have been upward and downward trends in capital gains variable during the period 1976q2 through 2007q3. Table 1/Histogram shows that the distribution of $\pi(\mathrm{t})$ percent/year, is highly skewed to the right. These extreme observations are the bubble years. The distribution in table 1 is unlikely to be normal as seen by the low probability of the Jarque-Bera statistic. The median appreciation over the entire sample period is 5.2\% p.a. During the bubble period 20042007, the 30- year mortgage rate fluctuated between 6 and $6.5 \%$ pa. It is reasonable to argue that the longer run real appreciation of housing prices was not significantly greater than "the mortgage rate of interest". Over the longer run, there was "no free lunch".

A large debt is risky insofar as the first term in (8) becomes negative due to adverse shocks. A sufficient condition for the bubble to burst is that eq. (20) is succeed by eq. (22), that the capital gain $\pi(t)$ falls below $i(t)$ the interest on the debt. It is not necessary that $\pi<0$ prices decline.

(22) $\pi<\mathrm{i}$.

\section{BURST}

Term $(\beta(\mathrm{t})-\mathrm{i}(\mathrm{t}))$ was negative in the bubble years. When the bubble burst in year 2007, the cash flow plus the positive or negative capital gain was insufficient to service the debt $\beta(t)+$ $\pi(t)<i(t)$. The borrowers were not able to refinance/cash in the capital gain, at the low old interest rate. The net worth in equation (8) declined. The fatal error made by the market, as pointed out in part 1 above, was to discount the probability that that eqn. (20) would be followed by eqn. (22). 


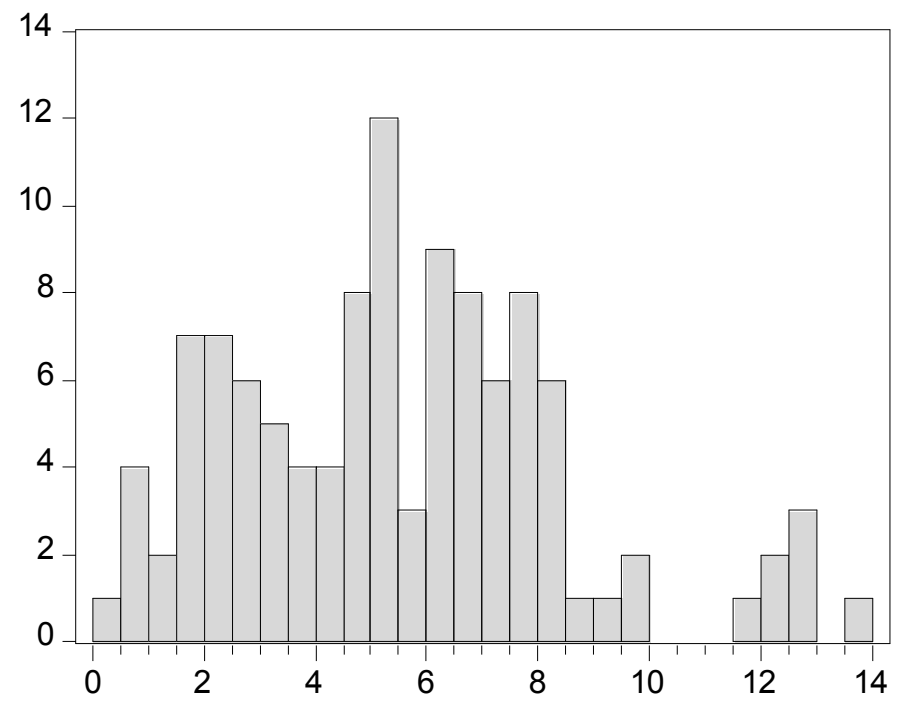

\begin{tabular}{|ll}
\hline Series: CAPGAIN \\
Sample 1980Q1 2007Q4 \\
Observations 111 \\
Mean & 5.436757 \\
Median & 5.220000 \\
Maximum & 13.50000 \\
Minimum & 0.270000 \\
Std. Dev. & 2.948092 \\
Skewness & 0.562681 \\
Kurtosis & 3.187472 \\
& \\
Jarque-Bera & 6.019826 \\
Probability & 0.049296
\end{tabular}

Table 1. Histogram and statistics of CAPGAINS, the four- quarter appreciation of US housing prices, percent/year: $\pi(t)=[\mathrm{P}(\mathrm{t}+1)-\mathrm{P}(\mathrm{t})] / \mathrm{P}(\mathrm{t})$. This is the same variable normalized in figure 1 .

\subsection{The Price equation ${ }^{5}$}

The unpredictable stochastic variable is the $\mathrm{dP}(\mathrm{t})$ term in equation $(8)$ for the change in net worth. Model I assumes that the logarithm of the price of the asset has a time trend $\rho$. This trend is constrained to be less than or equal to the nominal rate of interest, the no free lunch constraint. There is also a deviation $\mathrm{y}(\mathrm{t})$ between the logarithm of the price and the trend. The price $\mathrm{P}(\mathrm{t})$ satisfies (23) where $\mathrm{P}=\mathrm{P}(0)$. Deviation from trend $\mathrm{y}(\mathrm{t})$ is observable from observations of the price $\mathrm{P}(\mathrm{t})$, equation (24).

(23) $P(t)=P \exp [\rho t+y(t)], \rho \leq i$.

(24) $\mathrm{y}(\mathrm{t})=\ln \mathrm{P}(\mathrm{t})-\ln \mathrm{P}-\rho \mathrm{t}$,

Model I assumes that deviation $\mathrm{y}(\mathrm{t})$ is a zero mean Ornstein-Ulenbeck process, which is the solution of stochastic differential eqn.(25). Coefficients $\alpha$ and $\sigma$ are positive constants and w(t) is a Wiener process. The solution is that $\mathrm{y}(\mathrm{t})$ is normally distributed with a zero mean and a variance of $\left(\sigma^{2} / 2 \alpha\right)$, eqn. (25a).

(25) $d y(t)=-\alpha y(t) d t+\sigma d w(t), \quad y(0)=0$.

(25a) $\lim y(t) \sim N\left(0, \sigma^{2} / 2 \alpha\right)$.

\footnotetext{
${ }^{5}$ This model is inspired by the work of Platen-Rebello, Bielecki-Pliska and Fleming (1999, parts 2 and 4).
} 
From (23) and (24) using Ito's stochastic differential rule $\mathrm{dP}(\mathrm{t}) / \mathrm{P}(\mathrm{t})$ is

(26) $d P(t)=P(t)\left\{\left[\left(\rho+(1 / 2) \sigma^{2}-\alpha y(t)\right] d t+\sigma d w(t)\right\}\right.$

Equation (26) corresponds to eqn. (9). Drift a(t) in the general model is eqn. (27) in model I.

(9) $d P(t)=P(t)[a(t) d t+\sigma d w(t)] . \quad$ General Model

(27) $a(t)=\left[\left(\rho+(1 / 2) \sigma^{2}-\alpha y(t)\right] . \quad\right.$ Model I

From (24), (25) and (27), it follows that a(t) is observable from observations of the price history. Notice that price $\mathrm{P}(\mathrm{t})$ will have a downward or an upward drift insofar as $\mathrm{y}(\mathrm{t})$ is greater or less than $\left[\rho+(1 / 2) \sigma^{2}\right] / \alpha$.

\subsection{Optimization}

Substitute the value of $\mathrm{a}(\mathrm{t})$ from eqn. (27) into equation (15) for the general model. One obtains eqn. (28) for the optimal debt ratio $\mathrm{f}^{*}(\mathrm{t})$ in Model I. Each component is observable.

Model I. Optimal debt/net worth.

$\left.(28) \mathrm{f}^{*}(\mathrm{t})=\left\{\left[\beta(\mathrm{t})-(\mathrm{i}(\mathrm{t})-\rho)-(1 / 2) \sigma^{2}\right]-\alpha y(\mathrm{t})\right\} / \sigma^{2}=\left\{[\beta(\mathrm{t})-\mathrm{r}(\mathrm{t})]-(1 / 2) \sigma^{2}\right]-\alpha y(\mathrm{t})\right\} / \sigma^{2}$ real rate of interest $r(t)=i(t)-\rho \geq 0$.

The first component of eq. $(28),\left[\beta(t)-r(t)-(1 / 2) \sigma^{2}\right]$ is the risk adjusted difference between the current productivity of capital and the current real rate of interest. The condition $r(t) \geq 0$ means that the estimate of the trend cannot exceed the rate of interest. The second term $y(t)$ is the deviation of the price of the asset from its long term trend (eqn. 24).

\section{Model II. Two State Markov Jump Process}

Model II is inspired by Rishel (2006) which has several similarities with the one by BlanchetScalliet et al (2007). The basic idea is that the probabilistic drift term a(t) in eqn. (9) above is described by eqn.(29). The first component $\rho$ is a long term price trend that is not greater than the mean nominal rate of interest. The second is jump Markov process with states $a>0$ and $b<$ 0 . When the process is in state $\mathrm{a}>0$, prices are growing faster than trend, and when the process is in state $b<0$, the prices are growing below trend. Assume that the Markov process has a generator where the expected time that the drift is in good state a $>0$ is $(1 / \mathrm{c})$, and the expected time that the drift is in the bad state $\mathrm{b}<0$ is $(1 / \mathrm{k})$. The conditional probability that the system is in the good state $\mathrm{a}>0$ is $1>\mathrm{g}(\mathrm{t})>0$.

(29) $a(t)=\rho+a g(t)+b(1-g(t)), \quad a>0>b$. 
Equation (30) based upon (29) corresponds to eqn. (9) in the general model. In addition to the probabilistic drift, there is the innovation term $\sigma \mathrm{d} v(\mathrm{t})$, where $v(\mathrm{t})$ is a Wiener process. (30) $d P(t) / P(t)=[\rho+a g(t)+b(1-g(t)] d t+\sigma d v(t)$

Substitute the value of $\mathrm{a}(\mathrm{t})$ in eqn. (29) in the equation (15) of the general Model to derive eqn. (31), the optimal debt ratio in Model II. Define the real rate of interest $r(t)$ as the nominal rate of interest $\mathrm{i}(\mathrm{t})$ less the long term drift $\rho$, and constrain $\mathrm{r}(\mathrm{t})$ to be non-negative.

Model II. Optimal ratio of debt/net worth

$(31) f^{*}(t)=\left[\beta(t)-r(t)+a g(t)+b(1-g(t))-\sigma^{2}\right] / \sigma^{2} \quad r=i-\rho \geq 0$.

Rishel provides structure to conditional probability $\mathrm{g}(\mathrm{t})$. Nonlinear filtering results imply that the stochastic differential equation for the conditional probability ${ }^{6} \mathrm{~g}(\mathrm{t})$ is eqn. (32). The innovation term is $\mathrm{d} v(\mathrm{t})$, where $v(\mathrm{t})$ is a Wiener process. The limit of the conditional expectation $\mathrm{g}(\mathrm{t})$ is the expected fraction of time that the drift is in the good state. Thus $\lim \mathrm{E}[\mathrm{g}(\mathrm{t})]=\mathrm{g}^{*}=$ $\mathrm{k} /(\mathrm{c}+\mathrm{k})$ in eqn. $(32 \mathrm{a})$.

(32) $d g(\mathrm{t})=[-\operatorname{cg}(\mathrm{t})+\mathrm{k}(1-\mathrm{g}(\mathrm{t}))] \mathrm{dt}+((\mathrm{a}-\mathrm{b}) / \sigma) g(\mathrm{t})(1-\mathrm{g}(\mathrm{t})) \mathrm{d} v(\mathrm{t})$

(32a) $\lim \mathrm{E}[\mathrm{g}(\mathrm{t})]=\mathrm{g} *=\mathrm{k} /(\mathrm{c}+\mathrm{k})=$ expected fraction of time in good state.

The productivity of capital $\beta(\mathrm{t})$ and the rate of interest $\mathrm{i}(\mathrm{t})$ are observable. The conditional probability $\mathrm{g}(\mathrm{t})$ is not observable; however, the expected fraction of time in the good state (where prices are rising faster than the long-term trend), $\mathrm{g}^{*}$ and risk $\sigma$ can be estimated from figure 1 and table 1 over the sample period. One could use $g(t)=g^{*}=k /(c+k)$ in (31) to derive another estimate of the optimal debt ratio, eq. (31a).

(31a) $f^{*}(t)=\left[\beta(t)-r(t)+a k /(c+k)+b(1-k /(c+k))-\sigma^{2}\right] / \sigma^{2} \quad r=i-\rho \geq 0$.

Thus the estimates of the optimal debt ratio $f^{*}(t)$ from eq. (28) and (31a) - but not from (31) where $g(t)$ is the solution of (32) - can be compared with the actual debt ratio $f(t)$. In any event eqn. (18) shows the errors resulting from misspecification.

\section{Application to Subprime Mortgage Crisis ${ }^{7}$}

Recall Greenspan's statement: "This modern risk-management paradigm held sway for decades. The whole intellectual edifice, however, collapsed in the summer of last year [2007]'”.

\footnotetext{
${ }^{6}$ See Rishel for the proofs. A similar analysis is in Blanchet-Scalliet et al.

${ }^{7}$ Crouhy et al provide a detailed description of the Subprime Mortgage Crisis of 2007.
} 
On the basis of the stochastic optimal control analysis in this paper, we answer the following questions. What is an optimal debt ratio? How should one measure an excessive debt? What are Early Warning Signals (EWS) of a debt crisis? A caveat is that even models designed by geniuses are subject to error and uncertainties. One can never be sure what is the correct way to model the stochastic processes. For this reason, I use both Models I and II to estimate $f^{*}(t)$ the optimal debt ratio. Equation (18)/fig. 2 show the how errors of estimate of the optimal debt ratio $f^{*}(t)$ affect the expected growth of net worth.

The analysis proceeds in two parts. First, we explain what determined $f(t)$ the actual debt ratio that led to the crisis. It seems that the market optimized what I call Model III. Second, we present the EWS in a relatively general way that is compatible with both constrained optimizing models I and II. Our strategy is to estimate the excess debt $\Psi(\mathrm{t})=\mathrm{f}(\mathrm{t})-\mathrm{f}^{*}(\mathrm{t})$ and use it in the manner suggested by figure 2/eqn. (18). Our EWS, based upon the standard deviation of the excess debt, stresses the probabilistic nature of the analysis.

\subsection{The Bubble and Collapse}

Demyanyk and Van Hemert (D-VH) had a data base consisting of one half of the US subprime mortgages originated during the period 2001-2006. I interpret their study on the basis of the SOC analysis above. At every mortgage age, loans originating in 2006 had a higher delinquency rate than in all the other years since 2001. They examined the relation between the probability $\Pi$ of delinquency/foreclosure/binary variable $z=\{1,0\}$, denoted as $\Pi=\operatorname{Pr}(\mathrm{z})$ and sensible economic variables, vector $\mathrm{X}$. They investigated to what extent a logit ${ }^{8}$ regression $\Pi=\operatorname{Pr}(\mathrm{z})=\Phi(\beta \mathrm{X})$ can explain the high level of delinquencies of vintage 2006 mortgage loans. Vector $\beta$ is the estimated regression coefficients.

They estimated vector $\beta$ based upon a random sample of one million first-lien subprime mortgage loans originated between 2001 and 2006. The first part to their study provides estimates of $\beta$, the vector of regression coefficients and the importance of the variables in vector $\mathrm{X}$. The second part inquires why the year 2006 was so bad. The approach is based upon the equation (33). The contribution $\mathrm{C}(\mathrm{i})$ of component $\mathrm{X}_{\mathrm{i}}$ in vector $\mathrm{X}$ to the probability of default in year 2006 relative to the mean is:

\footnotetext{
${ }^{8}$ A logit model specifies that the probability that $\mathrm{z}=1$ is: $\operatorname{Pr}(\mathrm{z}=1)=\exp (\mathrm{X} \beta) /[1+\exp (\mathrm{X} \beta)]$. Hence $\ln \{\operatorname{Pr}(\mathrm{z}=1) / \operatorname{Pr}(\mathrm{z}=0)\}=\mathrm{X} \beta$.
} 
(33) $\mathrm{C}(\mathrm{i})=\left(\delta \Pi / \delta \mathrm{X}_{\mathrm{i}}\right) \mathrm{d} \mathrm{X}_{\mathrm{i}}=\Phi\left(\beta \mathrm{X}_{\mathrm{m}}+\beta_{\mathrm{i}} \mathrm{d} \mathrm{X}_{\mathrm{i}}\right)-\Phi\left(\beta \mathrm{X}_{\mathrm{m}}\right), \quad \mathrm{m}=$ mean value

The probability of delinquency when the vector $X$ is at its mean value is $\Phi\left(\beta X_{m}\right)$. The added probability resulting from the change in component $X_{i}$ in 2006 comes from $\beta_{i} d X_{i}$ where $\beta_{i}$ is the regression coefficient of element $X_{i}$ whose change was $d X_{i}$.

Table 2 below (based upon D-VH, table 3) displays the largest factors that made the delinquencies and foreclosures in year 2006 worse than the mean over the entire period. For year 2006, the largest contribution to delinquency and to foreclosure was the low house price appreciation. It accounted for $1.08 \%$ of the greater delinquencies and $0.61 \%$ for the greater foreclosures. The debt/income, the balloon dummy and the documentation variables are significantly smaller.

Table 2. Contribution C(i) of factors to probability of delinquency and defaults 2006, relative to mean for the period 2001-2006. Source: D-VH, table 3.

\begin{tabular}{|l|l|l|}
\hline $\begin{array}{l}\text { Variable X(i), see D-VH } \\
\text { table } 2 \text { for definitions }\end{array}$ & $\begin{array}{l}\text { Contribution C(i) to } \\
\text { delinquency rate }\end{array}$ & $\begin{array}{l}\text { Contribution C(i) to } \\
\text { foreclosure rate }\end{array}$ \\
\hline House price appreciation & $1.08 \%$ & $0.61 \%$ \\
\hline Balloon & 0.18 & 0.09 \\
\hline Documentation & 0.16 & 0.07 \\
\hline Debt/income & 0.15 & 0.04 \\
\hline
\end{tabular}

Table 2, the sketch of the sub-prime mortgage story in part 1 and the violation of the "no free lunch" constraint in part (3.1) above explain how the excess debt $\Psi(\mathrm{t})$ led to the crisis. The bubble started with eq. (20). Risk was assumed to be low because of the high capital gains relative to the interest rate, and value of collateral/equity was rising. An entire structure of financial instruments/derivatives was based upon these mortgages. The collapse occurred when eqn. (22) occurred. This is consistent with the table above.

\subsection{Model III}

The market seems to have followed Model III where the estimate of drift a(t) in the general price equation (9) was Bayesian ${ }^{9}$ equation (34). The posterior estimate of the drift a(t+1)

\footnotetext{
${ }^{9}$ I am drawing upon DeGroot chapter 9 for an analysis of Bayesian estimation.
} 
is a linear combination of the prior $\mathrm{a}(\mathrm{t})$ and a sample which is the recent price appreciation $\pi(\mathrm{t})=$ $[\mathrm{P}(\mathrm{t}+1)-\mathrm{P}(\mathrm{t})] / \mathrm{P}(\mathrm{t})$. For simplicity assume that the weight $1>\mathrm{m}>0$ is constant. Solve (34) for $\mathrm{a}(\mathrm{t})$ and derive (35), whose limit is (36). The drift $\mathrm{a}(\mathrm{t})$ converges to recent capital gains $\pi(\mathrm{s})$, where (t-s) is distance from present time t. Therefore the "optimal" debt ratio selected by the market is eqn. (37), where drift (36) is substituted into the optimal debt ratio eqn. (15) for the general case.

Market/ Model III

(34) $\mathrm{a}(\mathrm{t}+1)=\mathrm{ma}(\mathrm{t})+(1-\mathrm{m}(\mathrm{t})) \pi(\mathrm{t}), \quad 1>\mathrm{m}>0$

(35) $\mathrm{a}(\mathrm{t}+1)=\mathrm{a}(0) \mathrm{m}^{\mathrm{t}+1}+(1-\mathrm{m}) \Sigma \pi(\mathrm{s}) \mathrm{m}^{\mathrm{t}-\mathrm{s}} . \quad \mathrm{t} \geq \mathrm{s} \geq 0$

(36) $\lim \mathrm{a}(\mathrm{t})=(1-\mathrm{m}) \Sigma \pi(\mathrm{s}) \mathrm{m}^{\mathrm{t}-\mathrm{s}}$

(37) $f(t)=\left[(1-m) \Sigma \pi(s) m^{t-s}+\beta(t)-i(t)-\sigma^{2}\right] / \sigma^{2}$

Table 1 describes the statistics underlying the capital gains variable CAPGAIN $=\pi(\mathrm{t})$, which is the four- quarter appreciation of US housing prices. The distribution is highly skewed to the right. These extreme observations are the bubble years. During the period 2005-2006, the actual capital gains ranged from $12 \%$ to $13 \%$ per annum. There were no significant declines in housing prices during the sample period in table 1 . The 30 -year mortgage interest rate, during 2004-07, fluctuated between 6 to $6.5 \%$ per annum. Hence the market estimated drift in (34)/(36) is dominated by recent $\pi(\mathrm{t})$. This means that $\mathrm{a}(\mathrm{t})-\mathrm{i}(\mathrm{t}) \sim \pi(\mathrm{t})-\mathrm{i}(\mathrm{t}) \sim 0.12-0.06=0.06$ per year. Hence the market assume that the "optimal debt ratio" $\mathrm{f}(\mathrm{t})$ was quite high, as seen in figure 1.

There are several grave deficiencies to Model III. First, it ignores the economic constraint that there is "no free lunch/ no money machine". As was explained in part 3.1 above, one cannot continue to borrow and spend, and pay the interest from the capital gain. A situation where there is a "free lunch" or "money machine" where $[(\pi(t)-\mathrm{i}(\mathrm{t})]>0$ is not sustainable.

The second deficiency of Model III concerns an economic feedback from the prior a(t) to the subsequent "sample" or capital gain $\pi(t+1)$ in eq. (34). The market debt ratio $f(t)$ in the Model III/eq. (37) was highly influenced by $\pi(t)$, the recent capital gains. Recent price appreciation induced the market to raise the estimate of future drift. The demand for the asset rose, which further raised the price. This feedback from the prior a(t) to the subsequent "sample" $\pi(t+1)$ produced the illusion of a "free lunch". The optimal debt ratio should have been based upon Model I/eq. (28) or Model II/eq.(31a), where the drift was constrained. 


\section{Estimates of Excess Debt, Early Warning Signal of a Crisis}

An Early Warning Signal of a debt crisis is a series of excessive debts $\Psi(t)=f(t)-f^{*}(t)>0$. As shown in figure 2/eq. (19), the loss of growth from non optimal debt ratios over a period $(0, \mathrm{~T})$ is (19) $\mathrm{E}\left[\ln \mathrm{X}^{*}(\mathrm{~T})-\ln \mathrm{X}(\mathrm{T})\right]=\int^{\mathrm{T}}\left[\mathrm{W}^{*}(\mathrm{t})-\mathrm{W}(\mathrm{t})\right] \mathrm{dt}=(1 / 2) \int^{\mathrm{T}} \sigma^{2} \Psi(\mathrm{t})^{2} \mathrm{dt}$.

When the debt ratio $\mathrm{f}(\mathrm{t})$ exceeds $\mathrm{f}$-max in figure 2 , the expected growth is negative. A crisis is likely when $\int{ }^{\mathrm{T}} \sigma^{2} \Psi(\mathrm{t})^{2} \mathrm{dt}$ is large. The next question is: What are the appropriate measures of the actual and the optimal debt ratio to evaluate $\Psi(\mathrm{t})$ ? For reasons discussed below, I use normalized variables where the normalization $(N)$ of a variable $Z(t)$ called $N(Z)=[Z(t)-$ mean $Z] /$ standard deviation. The mean of $N(Z)$ is zero and its standard deviation is unity.

For the actual debt ratio I shall use the debt burden $\mathrm{i}(\mathrm{t}) \mathrm{L}(\mathrm{t}) / \mathrm{Y}(\mathrm{t})$. There is a great heterogeneity in interest rates charged to the subprime borrowers depending upon the terms of the mortgage, so it is difficult to state exactly what corresponds to $i(t)$ in the analysis above. I therefore use "Household Debt Service Payments as a Percent of Disposable Personal Income"10 as a measure of $\mathrm{iL} / \mathrm{Y}$ the debt burden. This includes all household debt, not just the mortgage debt, because the capital gains led to a general rise in consumption and debt. The normalized value of the debt service $\mathrm{N}(\mathrm{f})$ or debt burden, is equation (38), which is graphed in figure 3 as DEBTSERVICE. This is measured in units of standard deviations from the mean of zero. There is a dramatic deviation above the mean from 1998 to 2006.

(38) $\mathrm{N}(\mathrm{f})=[\mathrm{f}(\mathrm{t})-$ mean $)] /$ standard deviation

$\sim$ DEBTSERVICE $=[\mathrm{i}(\mathrm{t}) \mathrm{L}(\mathrm{t}) / \mathrm{Y}(\mathrm{t})-$ mean $] /$ standard deviation.

As noted in the introduction, one can never be sure what is the correct way to model the stochastic processes. Therefore a rather flexible approach will be taken to estimate the optimal debt ratio $\mathrm{f}^{*}(\mathrm{t})$, so that it captures the essence of alternative optimal debt ratios from Model I and Model II.

The optimum debt ratio $\mathrm{f}^{*}$ based upon Model I is eqn. (28). From the histogram of the capital gains in table 1, the mean capital gain was 5.4\% per annum with a standard deviation of $2.9 \%$. It is reasonable to argue that, over a long period, the longer run real appreciation of housing prices was not significantly different from "the mortgage rate of interest", $(i-\rho)=r=0$. The optimal debt ratio from (28) should be (28a) below. In Model II the optimal debt ratio is

\footnotetext{
${ }^{10}$ This is series TDSP in FRED.
} 
(31), but conditional expectation $\mathrm{g}(\mathrm{t})$ is not observable. However, the limit of the expectation $\operatorname{Eg}(\mathrm{t})=\mathrm{g}^{*}=\mathrm{k} /(\mathrm{c}+\mathrm{k}) *$ is observable.

(28a) $f^{*}(t)=\left[\left(\beta(t)-(1 / 2) \sigma^{2}-\alpha y(t)\right] / \sigma^{2} . \quad\right.$ Model I.

(31) $f^{*}(t)=\left[\beta(t)-r(t)+a g(t)+b(1-g(t))-\sigma^{2}\right] / \sigma^{2} \quad r=i-\rho \geq 0$. Model II

Normalize the optimum debt ratios from Models I and II, respectively. Thereby equation $(39 / \mathrm{I})$ is obtained from Model I/eq. (28a). The expected deviation $\mathrm{Ey}(\mathrm{t})=0$ and $\beta=\mathrm{E} \beta(\mathrm{t})$.

Equation (40/II) is obtained from (31) by assuming that $\mathrm{r}(\mathrm{t})=\mathrm{i}(\mathrm{t})-\rho=0$.

$(39 / \mathrm{I}) \quad \mathrm{N}\left(\mathrm{f}^{*}\right)=\{[(\beta(\mathrm{t})-\beta)]-\alpha y(\mathrm{t})\} / \sigma(\beta)$

$\left.(40 / \mathrm{II}) \mathrm{N}\left(\mathrm{f}^{*}\right)=[(\beta(\mathrm{t})-\beta)]+[(\mathrm{a}-\mathrm{-b})(\mathrm{g}(\mathrm{t})-\mathrm{g} *)]\right\} / \sigma(\beta)$

The common feature for both models is $[(\beta(t)-\beta)]$ the deviation of the return on capital from its mean value over the entire period. We must estimate $\beta(\mathrm{t})$, the productivity of capital. The productivity of housing capital is the implicit net rental income/value of the home plus a convenience yield in owning one's home. Assume that the convenience yield in owning a home has been relatively constant. Approximate the return $\beta(\mathrm{t})$ by using the ratio of rental income/disposable personal income ${ }^{11}$. One has data for each variable in Model I/ eq (28a) (39/I). For Model II the conditional probability $\mathrm{g}(\mathrm{t})$, that the drift is in state $\mathrm{a}>0$, is unobservable. However, $\mathrm{g}^{*}=\mathrm{k} /(\mathrm{c}+\mathrm{k})$ is observable, see figure 1 .

The common core for the optimal ratio in both models is term $[(\beta(t)-\beta)] / \sigma(\beta)$. In figure 3/eqn. (41) variable RENTRATIO is the normalized return, measured in units of standard deviation from the mean.

(41) $\mathrm{N}\left(\mathrm{f}^{*}\right) \sim[\beta(\mathrm{t})-\beta] / \sigma(\beta)=$ RENTRATIO $\quad \beta=\mathrm{E} \beta(\mathrm{t})=$ mean

$=($ rental income $/$ disposable personal income - mean $) /$ standard deviation .

The next question is how to estimate the excess debt $\Psi(\mathrm{t})$ that corresponds to eq.18/figure 2 , and is consistent with alternative estimates of the optimal debt.

The approach used here is to estimate excess debt $\Psi(\mathrm{t})=\left(\mathrm{f}(\mathrm{t})-\mathrm{f}^{*}(\mathrm{t})\right)$ by using the difference between two normalized variables $N(f)-N\left(f^{*}\right)$, equation (42). This difference is measured in standard deviations.

(42) $\Psi(\mathrm{t}) \sim \mathrm{N}[\mathrm{f}(\mathrm{t})]-\mathrm{N}\left[\mathrm{f}^{*}(\mathrm{t})\right]=$ DEBTSERVICE - RENTRATIO.

${ }^{11} \mathrm{I}$ do not have reliable estimates of $\mathrm{K}(\mathrm{t})$ the value of housing. 


\subsection{Early Warning Signals}

An Early Warning Signal EWS is that the excess debt, based upon the common core of Models I and II, is significantly large - measured in standard deviations. Each term in Model I eq. (39/I), is observable. Hence equation (42) can be supplemented by an estimate of $y(t)$ the deviation of the price from trend. The trend used must not be greater than the rate of interest. An $E W S$, based upon an excess debt $\Psi(\mathrm{t})=\mathrm{N}[\mathrm{f}(\mathrm{t})]-\mathrm{N}\left[\mathrm{f}^{*}(\mathrm{t})\right]$, can be seen as the difference between the two curves graphed in figure 3. Assume that over the entire period $1980-2007$ the debt ratio was not excessive. Figure 1 shows that, over the period 1980 - 2004, the capital gains exceeded the mean for several years and fell below it for another period of time. The histogram table 1 shows that the mean capital gain $\pi(\mathrm{t})=[\mathrm{P}(\mathrm{t}+1)-\mathrm{P}(\mathrm{t})] / \mathrm{P}(\mathrm{t})=5.4 \%$ pa was close to the mortgage rates of interest from $2004 \mathrm{q} 1$ to $2008 \mathrm{q} 1$ ranging from 5.7 to $6.2 \%$ pa.

After 2004, very clear EWS are seen from figure 3. First, the optimal debt ratio $f^{*}(t)$, measured by normalized RENTRATIO/eq. (41) common to both Models I and II, was significantly below ${ }^{12}$ the normalized actual/market ratio, measured by DEBTSERVICE. Second, from 2003 to 2004, the capital gains exceeded the mean. Hence in Model I/eq. (39/I) deviation $y(t)$ was positive. By either estimate of the optimal debt, Model I eq. (39/I) or the common core of Models I and II, eq. (41)/graph RENTRATIO, there was an excess debt $\Psi(\mathrm{t})>0$.

The actual debt was induced by $[\pi(\mathrm{t})-\mathrm{i}(\mathrm{t})]$, the high capital gains and low interest rates during 2002 - 2005. See market equation (37). From year 2000, the productivity of capital RENTRATIO was not rising, but the debt ratio was significantly above its mean and rising rapidly. The rising debt could only be serviced from capital gains. The excess debt $\Psi(\mathrm{t})=\mathrm{N}[\mathrm{f}(\mathrm{t})]$ $-\mathrm{N}\left[\mathrm{f}^{*}(\mathrm{t})\right]$ in 2004 was two standard deviations. Deviation $\Psi(t)$ of more than two standard deviations is an EWS of a crisis.

12 The rent ratio is rental income/disposable personal income. The numerator, which is actual rental income, series RENTIN in data bank FRED, fell drastically. 


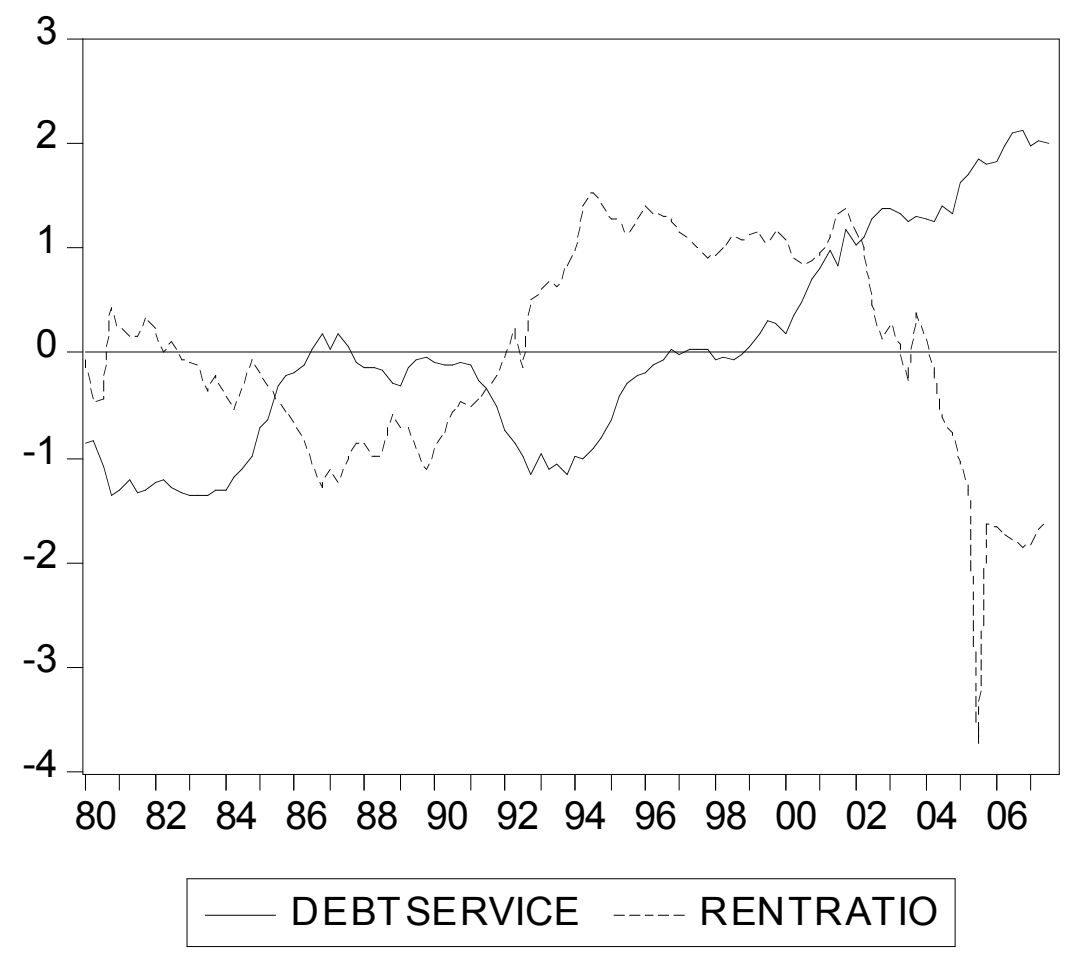

Figure 3. Early Warning Signals: Excess debt $\Psi(\mathrm{t})=\mathrm{N}[\mathrm{f}(\mathrm{t})]-\mathrm{N}\left[\mathrm{f}^{*}(\mathrm{t})\right]$. $\mathrm{N}[\mathrm{f}(\mathrm{t})]=$ DEBTSERVICE $=$ (household debt service as percent of disposable income mean)/standard deviation.

$\mathrm{N}\left[\mathrm{f}^{*}(\mathrm{t})\right]=\mathrm{RENTRATIO}=($ rental income/disposable personal income - mean $) /$ standard deviation; Sources FRED.

The only thing that held off the crisis was the capital gain in excess of the interest rate. As soon as the appreciation $\pi(\mathrm{t})$ became less than interest rate $\mathrm{i}(\mathrm{t})$, there would be no capital gains that could be converted into cash to pay the interest. There was a high probability that shocks would lower net worth. When eq. (20) inevitably becomes eqn (22), a crisis is expected with the consequent delinquencies, bankruptcies and defaults. This indeed occurred. As D-VH found, the most significant variable in explaining why year 2006 was so bad was that housing price appreciation disappeared. (i) Falling housing prices was the most significant variable accounting for the rise in the delinquency and default rates in table 1. (ii) There was a negative correlation between the rate of house-price appreciation and level of sub-prime delinquencies among metropolitan statistical areas ${ }^{13}$.

${ }^{13}$ See Federal Reserve Bank of San Francisco (2007). 


\section{Conclusions}

Why did the financial markets fail to anticipate the recent debt crises, despite the large literature in mathematical finance concerning optimal portfolio allocation and stopping rules? What lessons should be learned from the crisis?

The object of optimal risk management is to select a ratio of debt/net worth that will maximize the expected growth of net worth, equal to capital less debt. This is a risk averse strategy. The growth of net worth depends upon several stochastic variables: the asset price, the interest rate and productivity of capital. This paper derives an optimal debt/net worth ratio and explains what are the consequences of having a debt ratio that exceeds the optimal. In the period 2003 - 07, the debt ratio was excessive. Too much risk was assumed for the expected return.

The mathematical finance literature concerning credit risk used by the "Quants" is mainly concerned with transferring risk to other institutions. In this paper, a more macroeconomic approach stresses systemic risk, a row of dominos. The optimizer in this paper must be the industry as a whole.

No one can be sure what is the correct model. An optimal debt ratio is derived in a general model where the drift of the price of the asset is probabilistic. Several special cases are considered. Each model imposes an economic constraint that the trend of the asset price cannot exceed the mean rate of interest. Otherwise, a "free lunch" is possible: borrow to purchase the asset and refinance/pay the interest from the capital gains.

The optimal debt ratio is derived in each model. Model I assumes that the asset price has a trend and the deviation from this trend is an Ornstein-Ulenbeck ergodic mean reversion process. The derived optimal debt ratio contains observable and measurable variables. Model II also contains a probabilistic drift above and below this trend. Both Models I and II imply that the optimal debt ratio depends positively upon the difference between the current productivity of capital and its mean value, divided by the standard deviation. Model I implies that the optimal debt ratio also depends negatively upon the deviation of the asset price from its long-term trend, which cannot exceed the interest rate. When the return to capital is below its mean and the asset price is its long term trend, the optimal debt ratio should be reduced.

Model III describes the "market optimization". The market used a Bayesian analysis of the price drift. The posterior estimate of the drift was a weighted average of the prior and the recent price trend. The latter exceeded the rate of interest from 2000 to 2004 . The high posterior 
estimate of the drift led to an excessive debt and the bubble. The market ignored the "no free lunch" constraint" where the interest on the debt could only be paid from the capital gain. Moreover, "Herd behavior" leading to bubbles was generated. Recent capital gains raise the posterior, which in turn induces a demand for the asset, which raises the price that in turn further raises the subsequent prior.

The vulnerability of the borrowing firm to shocks from either the return to capital, the interest rate or capital gain, increases in proportion to the difference between the Actual and Optimal debt ratio, called the excess debt. A general operational measure of excess debt is derived and, on the basis of stochastic models I and II, we show that it is an early warning signal of the recent crisis. The market debt ratio deviated considerably from either estimate of the constrained optimal in Models I and II.

This interdisciplinary paper is aimed at both applied mathematicians who are looking for applications of the mathematics and to economists who may be looking for analytical tools for purposes of policy. 


\section{REFERENCES}

Beckmann, Martin Speculation Under the Random Walk Hypothesis, Pacific Economic Review, 7:2 (2002).

Bielecki, T. and S. Pliska Risk sensitive dynamic asset management, Appl. Math. Optim. 39 (1999), 337-60.

Blanchet-Scalliet, C., A. Diop, R. Gibson, D. Talay and E. Tancré, Technical analysis compared to mathematical models based under parameters mis-specification, Journal Banking and Finance, 31 (5) May 2007.

Crouhy, Michel, R. A. Jarrow and Stuart M. Turnbull, The Subprime Credit Crisis of 07, Journal of Derivatives, Fall 2008.

DeGroot, M. Optimal Statistical Decisions, McGraw Hill, 1970.

Demyanyk, Yulia and Otto Van Hemert, Understanding the Subprime Mortgage Crisis, Federal Reserve Bank, St. Louis, WP, October, 2007, SSRN

Federal Reserve Bank San Francisco, Economic Letter, Housing Prices and Subprime Mortgage delinquencies, June 2007.

Federal Reserve bank St. Louis, Economic Data - FRED.

Fleming, Wendell H. Controlled Markov Processes and Mathematical Finance, in F. H. Clarke and R.J.Stern (ed.), Nonlinear Analysis. Differential Equations and Control, Kluwer, 1999.

Fleming, Wendell H. and H. M. Soner, Controlled Markov Processes and Viscosity Solutions, Springer, 2006.

Fleming, Wendell H. and Jerome L. Stein, Stochastic Optimal Control, International Finance and Debt, Jour. Banking \& Finance, 28 (2004), 979-996.

Gerardi, K., A. Lehnert, S. Sheelund and P. Willen, Making Sense of the Subprime Crisis, Brookings Papers, Fall 2008.

Karatzas, I. A Note on Bayesian detection of price change points with an expected near miss criterion, Statistical Decisions, 21 (1), 2003.

Lister, R.S. and A. N. Shiryayev, Statistics of Random Processes 1, General Theory, Springer Verlag 1977. 
Lowenstein, Roger, When Genius Failed: The Rise and Fall of Long-Term Capital management", (2000).

Platen, E. and R. Rebolledo, Principles for modeling financial markets, J. App. Prob. 33 (1996)

Rishel, Raymond, Whether to Sell or Hold a Stock, Communications in Information and Systems, 6 (3) 193-202, 2006

Stein, Jerome L., A Stochastic Optimal Control Modeling of Debt Crises, Mathematics of Finance, G. Yin and Q. Zhang (ed.) American Mathematical Society 351, 2004.

Stein, Jerome L., Optimal Debt and Endogenous Growth in Models of International Finance, Australian Economic Papers, Special Issue on Stochastic Models, 44 (2005), 389-413.

Stein, Jerome L. Stochastic Optimal Control, International Finance and debt Crises, Oxford University Press, 2006.

Yin, George and Q. Zhang (ed.) Mathematics of Finance, Contemporary Mathematics 351, American Mathematical Society (2004).

Zhang, Q. Stock Trading: An Optimal Selling Rule, SIAM. Journal Control and Optimizatin (40) 2001. 


\section{CESifo Working Paper Series}

for full list see www.cesifo-group.org/wp

(address: Poschingerstr. 5, 81679 Munich, Germany, office@cesifo.de)

2477 Gaëtan Nicodème, Corporate Income Tax and Economic Distortions, November 2008

2478 Martin Jacob, Rainer Niemann and Martin Weiss, The Rich Demystified - A Reply to Bach, Corneo, and Steiner (2008), November 2008

2479 Scott Alan Carson, Demographic, Residential, and Socioeconomic Effects on the Distribution of $19^{\text {th }}$ Century African-American Stature, November 2008

2480 Burkhard Heer and Andreas Irmen, Population, Pensions, and Endogenous Economic Growth, November 2008

2481 Thomas Aronsson and Erkki Koskela, Optimal Redistributive Taxation and Provision of Public Input Goods in an Economy with Outsourcing and Unemployment, December 2008

2482 Stanley L. Winer, George Tridimas and Walter Hettich, Social Welfare and Coercion in Public Finance, December 2008

2483 Bruno S. Frey and Benno Torgler, Politicians: Be Killed or Survive, December 2008

2484 Thiess Buettner, Nadine Riedel and Marco Runkel, Strategic Consolidation under Formula Apportionment, December 2008

2485 Irani Arraiz, David M. Drukker, Harry H. Kelejian and Ingmar R. Prucha, A Spatial Cliff-Ord-type Model with Heteroskedastic Innovations: Small and Large Sample Results, December 2008

2486 Oliver Falck, Michael Fritsch and Stephan Heblich, The Apple doesn't Fall far from the Tree: Location of Start-Ups Relative to Incumbents, December 2008

2487 Cary Deck and Harris Schlesinger, Exploring Higher-Order Risk Effects, December 2008

2488 Michael Kaganovich and Volker Meier, Social Security Systems, Human Capital, and Growth in a Small Open Economy, December 2008

2489 Mikael Elinder, Henrik Jordahl and Panu Poutvaara, Selfish and Prospective: Theory and Evidence of Pocketbook Voting, December 2008

2490 Maarten Bosker and Harry Garretsen, Economic Geography and Economic Development in Sub-Saharan Africa, December 2008

2491 Urs Fischbacher and Simon Gächter, Social Preferences, Beliefs, and the Dynamics of Free Riding in Public Good Experiments, December 2008 
2492 Michael Hoel, Bush Meets Hotelling: Effects of Improved Renewable Energy Technology on Greenhouse Gas Emissions, December 2008

2493 Christian Bruns and Oliver Himmler, It's the Media, Stupid - How Media Activity Shapes Public Spending, December 2008

2494 Andreas Knabe and Ronnie Schöb, Minimum Wages and their Alternatives: A Critical Assessment, December 2008

2495 Sascha O. Becker, Peter H. Egger, Maximilian von Ehrlich and Robert Fenge, Going NUTS: The Effect of EU Structural Funds on Regional Performance, December 2008

2496 Robert Dur, Gift Exchange in the Workplace: Money or Attention?, December 2008

2497 Scott Alan Carson, Nineteenth Century Black and White US Statures: The Primary Sources of Vitamin D and their Relationship with Height, December 2008

2498 Thomas Crossley and Mario Jametti, Pension Benefit Insurance and Pension Plan Portfolio Choice, December 2008

2499 Sebastian Hauptmeier, Ferdinand Mittermaier and Johannes Rincke, Fiscal Competition over Taxes and Public Inputs: Theory and Evidence, December 2008

2500 Dirk Niepelt, Debt Maturity without Commitment, December 2008

2501 Andrew Clark, Andreas Knabe and Steffen Rätzel, Boon or Bane? Others' Unemployment, Well-being and Job Insecurity, December 2008

2502 Lukas Menkhoff, Rafael R. Rebitzky and Michael Schröder, Heterogeneity in Exchange Rate Expectations: Evidence on the Chartist-Fundamentalist Approach, December 2008

2503 Salvador Barrios, Harry Huizinga, Luc Laeven and Gaëtan Nicodème, International Taxation and Multinational Firm Location Decisions, December 2008

2504 Andreas Irmen, Cross-Country Income Differences and Technology Diffusion in a Competitive World, December 2008

2505 Wenan Fei, Claude Fluet and Harris Schlesinger, Uncertain Bequest Needs and LongTerm Insurance Contracts, December 2008

2506 Wido Geis, Silke Uebelmesser and Martin Werding, How do Migrants Choose their Destination Country? An Analysis of Institutional Determinants, December 2008

2507 Hiroyuki Kasahara and Katsumi Shimotsu, Sequential Estimation of Structural Models with a Fixed Point Constraint, December 2008

2508 Barbara Hofmann, Work Incentives? Ex Post Effects of Unemployment Insurance Sanctions - Evidence from West Germany, December 2008 
2509 Louis Hotte and Stanley L. Winer, The Demands for Environmental Regulation and for Trade in the Presence of Private Mitigation, December 2008

2510 Konstantinos Angelopoulos, Jim Malley and Apostolis Philippopoulos, Welfare Implications of Public Education Spending Rules, December 2008

2511 Robert Orlowski and Regina T. Riphahn, The East German Wage Structure after Transition, December 2008

2512 Michel Beine, Frédéric Docquier and Maurice Schiff, International Migration, Transfers of Norms and Home Country Fertility, December 2008

2513 Dirk Schindler and Benjamin Weigert, Educational and Wage Risk: Social Insurance vs. Quality of Education, December 2008

2514 Bernd Hayo and Stefan Voigt, The Relevance of Judicial Procedure for Economic Growth, December 2008

2515 Bruno S. Frey and Susanne Neckermann, Awards in Economics - Towards a New Field of Inquiry, January 2009

2516 Gregory Gilpin and Michael Kaganovich, The Quantity and Quality of Teachers: A Dynamic Trade-off, January 2009

2517 Sascha O. Becker, Peter H. Egger and Valeria Merlo, How Low Business Tax Rates Attract Multinational Headquarters: Municipality-Level Evidence from Germany, January 2009

2518 Geir H. Bjønnes, Steinar Holden, Dagfinn Rime and Haakon O.Aa. Solheim, ,Large' vs. ,Small' Players: A Closer Look at the Dynamics of Speculative Attacks, January 2009

2519 Jesus Crespo Cuaresma, Gernot Doppelhofer and Martin Feldkircher, The Determinants of Economic Growth in European Regions, January 2009

2520 Salvador Valdés-Prieto, The 2008 Chilean Reform to First-Pillar Pensions, January 2009

2521 Geir B. Asheim and Tapan Mitra, Sustainability and Discounted Utilitarianism in Models of Economic Growth, January 2009

2522 Etienne Farvaque and Gaël Lagadec, Electoral Control when Policies are for Sale, January 2009

2523 Nicholas Barr and Peter Diamond, Reforming Pensions, January 2009

2524 Eric A. Hanushek and Ludger Woessmann, Do Better Schools Lead to More Growth? Cognitive Skills, Economic Outcomes, and Causation, January 2009

2525 Richard Arnott and Eren Inci, The Stability of Downtown Parking and Traffic Congestion, January 2009 
2526 John Whalley, Jun Yu and Shunming Zhang, Trade Retaliation in a Monetary-Trade Model, January 2009

2527 Mathias Hoffmann and Thomas Nitschka, Securitization of Mortgage Debt, Asset Prices and International Risk Sharing, January 2009

2528 Steven Brakman and Harry Garretsen, Trade and Geography: Paul Krugman and the 2008 Nobel Prize in Economics, January 2009

2529 Bas Jacobs, Dirk Schindler and Hongyan Yang, Optimal Taxation of Risky Human Capital, January 2009

2530 Annette Alstadsæter and Erik Fjærli, Neutral Taxation of Shareholder Income? Corporate Responses to an Announced Dividend Tax, January 2009

2531 Bruno S. Frey and Susanne Neckermann, Academics Appreciate Awards - A New Aspect of Incentives in Research, January 2009

2532 Nannette Lindenberg and Frank Westermann, Common Trends and Common Cycles among Interest Rates of the G7-Countries, January 2009

2533 Erkki Koskela and Jan König, The Role of Profit Sharing in a Dual Labour Market with Flexible Outsourcing, January 2009

2534 Tomasz Michalak, Jacob Engwerda and Joseph Plasmans, Strategic Interactions between Fiscal and Monetary Authorities in a Multi-Country New-Keynesian Model of a Monetary Union, January 2009

2535 Michael Overesch and Johannes Rincke, What Drives Corporate Tax Rates Down? A Reassessment of Globalization, Tax Competition, and Dynamic Adjustment to Shocks, February 2009

2536 Xenia Matschke and Anja Schöttner, Antidumping as Strategic Trade Policy Under Asymmetric Information, February 2009

2537 John Whalley, Weimin Zhou and Xiaopeng An, Chinese Experience with Global 3G Standard-Setting, February 2009

2538 Claus Thustrup Kreiner and Nicolaj Verdelin, Optimal Provision of Public Goods: A Synthesis, February 2009

2539 Jerome L. Stein, Application of Stochastic Optimal Control to Financial Market Debt Crises, February 2009 